\title{
Oral Hygiene Improvement using Combined Mouthwash with Plant extracts
}

\author{
Essam A. Makky ${ }^{1,3, *}$, Muna J. Ali ${ }^{2}$, and Mashitah M. Yusoff ${ }^{1}$
}

\begin{abstract}
${ }^{1}$ Faculty of Industrial Sciences \& Technology, Universiti Malaysia Pahang, 26300 Gambang, Kuantan, Pahang, Malaysia ${ }^{2}$ Department of pathological analyses, Al-Haweeja Technical Institute, Foundation of Technical Education, Northern Technical University, Kirkuk, Iraq

${ }^{3}$ Center of Excellence for Advanced Research in Fluid Flow (CARIFF), Universiti Malaysia Pahang, 26300 Gambang, Kuantan, Pahang, Malaysia
\end{abstract}

\begin{abstract}
Dental caries considered as one of the most common infectious diseases affecting mankind today, the dissolution of tooth structure by acid produced as a result of the fermentation of dietary carbohydrates by oral bacteria. The antimicrobial susceptibility of medicinal plants including black pepper, black cumin, cinnamon, cardamom on toothpaste and mouthwash against oral isolates for healthcare improvement was studied. Different oral isolates from 50 selected individuals aged 3 to 60 years were obtained from both genders, and a total of 59 bacterial and yeast isolates were collected, purified, and tested against four different commercial medicinal plants extracts for antimicrobial susceptibility profile. A total of 10 mouthwashes was purchased, and the combined action of the medicinal plants with mouthwash was studied against oral isolates. We found a higher bacterial population was in the age group of 3-40 years than other two groups, with approximately $44 \%$. In addition, the combined action of acetone plant extracts (alone) against oral isolates showed increasing effect profile up to $61.02 \%$ when combination $\mathrm{A}(\mathrm{Ci} / \mathrm{N})$ was added. Also, While, the combined action of medicinal plants with mouthwash was improved $100 \%$ with combination $\mathrm{C}$. We conclude that the combination $\mathrm{C}(\mathrm{P} / \mathrm{N} / \mathrm{Ca} / \mathrm{Ci})$ with mouthwash showed high susceptibility against oral isolates.
\end{abstract}

\section{Introduction}

Oral health is closely related to other health and quality of life issues. Oral hygiene is often a neglected susceptibility of daily living that has a major impact on general physical health. As soon as a baby is born, bacterial colonization of the mouth begins. In addition to frequent contact and sufficient inoculation size, colonization by oral bacteria requires a suitable attachment site and nutrients for growth. For example, children whose mouths are colonized by Streptococcus mutans are more likely to have been exposed to behaviour that allows for contact with adults' saliva and frequent sugar exposure than children without $S$. mutans [1]. Instead of performing the regular oral hygiene and dietary modifications to avoid dental caries, one of the effective methods by which oral hygiene can be achieved is through the uses of mouthwash. A mouthwash may be recommended to treat infection, reduce inflammation, relieve pain and reduce halitosis or to deliver fluoride locally for caries prevention. There are many brands of mouthwash marketed in Malaysia, each comes with its own deodorant, antiseptic, disinfectant, analgesic and astringent properties. Mouthwashes containing four phenol-related essential oils (thymol, eucalyptol, menthol and methyl salicylate in up to $26 \%$ alcohol) claim to penetrate the plaque biofilm and thus kill microorganisms that cause gingivitis. These mouthwashes display broad spectrum antimicrobial susceptibility, prevent bacterial aggregation, slow bacterial multiplication, retard plaque maturation and decrease plaque mass and pathogenicity. Their mechanism of action is thought to involve bacterial cell destruction, bacterial enzyme inhibition, and extraction of endotoxin from Gram-negative bacteria. Mouthwash improvement and development had been done mostly by the manufacturers and the little work that has been done relating to the individual ingredients as their main target to give freshness and eliminate oral bacterial, however, there are many doubts arise whether this mouthwash is really effective or not [2]. Medicinal plants have attracted increasing interest because of their antimicrobial susceptibility against pathogenic oral microorganisms. Plants that are used for traditional medicine contain a wide range of substances that can be used to treat chronic and infectious diseases [3]. The World Health Organization (WHO) estimates that $80 \%$ of the population of certain Asian and African countries presently uses medicinal plants in several aspects of primary health care. Studies in the United States and Europe have shown that the use of these plants is less common in clinical settings but has increased in recent

\footnotetext{
* Corresponding author: essam22001@gmail.com
} 
years, as scientific evidence regarding the effectiveness of herbal medicine has become more widely available [4]. Medicinal plants are important sources for pharmaceutical manufacturing and account for a significant percentage of the pharmaceutical market. For example, in Malaysia, the market for traditional medicine is estimated to be at 1 billion Malaysian ringgit annually [5]. However, an effective combination of medicinal plants in mouthwash against oral isolates has not been reported. The present study aims to obtain extracts combination of four commercial medicinal plants (black pepper, black cumin, cinnamon, cardamom) and screen its antibacterial susceptibility against oral isolates from different 50 selected individuals aged 3 to 60 years. In addition, the antimicrobial susceptibility of different commercial kinds of mouthwash were also evaluated against oral isolates.

\section{Methodology}

\subsection{Sample collection and Inoculum Preparation}

All oral isolates were collected by dentists from 50 selected individuals at dental clinic Gambang in Gambang, Pahang. Sterile swabs were used for selected individuals of both genders with ages ranging from 3 to 60 years. The collected samples were transferred to the laboratory at Universiti Malaysia Pahang. The oral samples were cultured onto sterile nutrient agar plates and incubated at $37^{\circ} \mathrm{C}$ for $24 \mathrm{~h}$, and then purified, cultured on agar slants, partial identified against Gram reaction and kept at $4^{\circ} \mathrm{C}$ in a chiller until use. After initial propagation, all test microbes were grown for 24 hours on Nutrient broth media at $37^{\circ} \mathrm{C}$, and inoculums for the assays were prepared by diluting. The density of each microbial suspension was adjusted using a spectrophotometer wavelength $600 \mathrm{~nm}$ (GENESYS 10S $\mathrm{UV}-\mathrm{Vis})$ to equal that of $0.5 \mathrm{McFarland}$ standards $\left(10^{8}\right.$ $\mathrm{CFU} / \mathrm{ml})$.

\subsection{Antimicrobial susceptibility test using disc diffusion method}

\subsubsection{Preparation of plants extracts}

The four plant parts were crushed using a blender and then sieved to obtain fine powders. Approximately $25 \mathrm{~g}$ of the powdered plants were soaked in $200 \mathrm{ml}$ of four different solvents $(95 \%$ ethanol, hot water, water, and acetone), kept at room temperature for $72 \mathrm{~h}$, and the suspension was then filtered through a Whatman No.1 filter paper. The filtrates were evaporated to $5 \mathrm{ml}$ the final concentration was $12.5 \%(\mathrm{~g} / \mathrm{v})$, using a rotary evaporator (BUCHI, Rotavapor R-3 Vacuum pump V$700)$, according to the modified method of [6].

\subsubsection{Combination of plant extracts}

The combination of plant extracts obtained using the four different solvents was studied at a ratio of 1:1 (v:v). Three different combination groups, A, B, and C, were prepared using the combination of two plant extracts together (A) $(\mathrm{P} / \mathrm{Ci}, \mathrm{P} / \mathrm{N}, \mathrm{P} / \mathrm{Ca}, \mathrm{Ci} / \mathrm{N}, \mathrm{Ci} / \mathrm{Ca}, \mathrm{N} / \mathrm{Ca})$, three extracts $(\mathrm{B})(\mathrm{P} / \mathrm{Ci} / \mathrm{N}, \mathrm{P} / \mathrm{Ci} / \mathrm{Ca}, \mathrm{P} / \mathrm{N} / \mathrm{Ca}, \mathrm{Ci} / \mathrm{N} / \mathrm{Ca})$, and all four extracts $(\mathrm{C})(\mathrm{P} / \mathrm{Ci} / \mathrm{N} / \mathrm{Ca})$, respectively. The extracts were stored in sterile bottles and stored at $4{ }^{\circ} \mathrm{C}$ until further use. Filter paper discs of $6 \mathrm{~mm}$ diameter were prepared using Whatman No. 1, UV sterilized, and loaded with $25 \mu \mathrm{l}$ plant extracts, left to dry, and then used an antibacterial screening test. All combinations were tested for antimicrobial susceptibility against oral isolates as previously mentioned.

\subsubsection{Plants extract against oral isolates}

Muller-Hinton agar medium was used for the antimicrobial susceptibility. The plants extract discs from previously prepared solvents as described in previous section were allowed to set onto the inoculated agar surface. Inoculum from primary culture plates were prepared, inoculating into a replicated plate, and incubation at $37{ }^{\circ} \mathrm{C}$ for $24 \mathrm{~h}$. After the incubation period, each plate was observed, and the inhibition zone of all isolates were recorded in millimetre ( $\mathrm{mm}$ ) [7] and calculated and represented as previously mentioned. The density of each bacterial suspension was adjusted using 0.5 McFarland standard. Control discs for different solvents were used.

\subsection{Selection of commercial Mouthwashes}

Ten different commercial mouthwashes (different brands), which were denoted by codes (Bac), (LTC), (FC), (SAC), (OB1), (Wat1), (CP), (Gu), (LCM), and (OX)

\subsubsection{Antimicrobial susceptibility test of mixture}

\subsubsection{Plant extract-mouthwash combination}

Ten different commercial types of mouthwash were mixed with the acetone plant extracts of combinations A, $\mathrm{B}$, and $\mathrm{C}$ at a ratio of $1: 1(\mathrm{v} / \mathrm{v})$ and antimicrobial susceptibility test performed as previously mentioned as described in pervious section and extract free mouthwash disc was used as a control.

\subsection{Statistical Analysis}

Statistical analyses were performed using ANOVA for data on disc agar diffusion assays, to test the antimicrobial susceptibility profile of oral isolates within medicinal plant extracts on the zone of inhibition using software Minitab 17. All antimicrobial susceptibility 
data were determined in diameter ( $\mathrm{mm})$, calculated and represented in this study as antimicrobial susceptibility percentage against all 59 oral isolates under study.

\section{Results and discussion}

\subsection{Oral Isolates}

Oral isolates were obtained from 50 different selected individuals of different ages and genders, and a total of 59 bacterial and yeast isolates were collected and purified as revealed in Table 1.

Table 1. The oral isolates in Gram reaction

\begin{tabular}{llcl}
\hline $\begin{array}{c}\text { Isolate } \\
\text { type }\end{array}$ & $\begin{array}{c}\text { Gram } \\
\text { reaction }\end{array}$ & $\begin{array}{c}\text { Number of } \\
\text { isolates }\end{array}$ & $\begin{array}{c}\text { Isolate } \\
\text { shape and } \\
\text { number }\end{array}$ \\
\hline Bacteria & $\begin{array}{l}\text { Gram } \\
\text { negative } \\
\text { Gram } \\
\text { positive }\end{array}$ & 2 & $\begin{array}{l}\text { Bacilli (1) } \\
\text { Cocci (1) } \\
\text { Bacilli (8) } \\
\text { Cocci (43) } \\
\text { Yeast }\end{array}$ \\
$\begin{array}{l}\text { Total } \\
\text { oral } \\
\text { isolates }\end{array}$ & & 61 & \\
\hline
\end{tabular}

The impact of age group on the infection rates of tooth caries showed that age groups of 3-20 and 20-40 years were more susceptible to infection than the older group of 40-60 years, with the incidence of 32 and $44 \%$, respectively as shown in Table 2 .

Table 2. The oral isolates in age group and percentage

\begin{tabular}{llcc}
\hline No. & $\begin{array}{c}\text { Age } \\
\text { group }\end{array}$ & $\begin{array}{c}\text { Selected individual } \\
\text { number }\end{array}$ & Percentage (\%) \\
\hline 1 & $3-20(\mathrm{Y})$ & 16 & 32 \\
2 & $20-40(\mathrm{Y})$ & 22 & 44 \\
3 & $40-60(\mathrm{Y})$ & 12 & 24 \\
\hline Total & & 50 & \\
\hline
\end{tabular}

Y: year
This finding may be related primarily to immune shortages of infected people, as well as more microbes were prevalent in younger person. Moreover, the emphasis has been placed on the function of the mother as a source of disease transmission from her infected teeth to the baby, as shown by the similar levels of bacteria in mothers to those found at their children [8].

\subsection{Combination of plant extracts using different solvents}

The results of antimicrobial susceptibility profile of 11 combinations as shown in Table 3 prepared, with the use of four different solvents to obtain medicinal plants extracts. Among acetone, ethanol, hot, and water extracts, the acetone extract of combination $\mathrm{A}(\mathrm{Ci} / \mathrm{N})$ showed antimicrobial susceptibility against 59 oral isolates with a higher synergistic effect up to $61.02 \%$ than other combinations, followed by acetone extract of combination B (P/N/Ca), with $30.51 \%$. The antimicrobial susceptibility against oral isolate $30.51 \%$ was observed in synergistic of group $\mathrm{C}$ of acetone extracts $(\mathrm{P} / \mathrm{Ci} / \mathrm{N} / \mathrm{Ca})$. The combination of aqueous extracts of medicinal plants did not exhibit an inhibitory effect against the tested oral microorganisms.

Table 3. Summary of antimicrobial susceptibility profile of plant extracts combination against oral isolates

\begin{tabular}{|c|c|c|c|c|c|}
\hline \multirow{2}{*}{$\begin{array}{l}\text { Group } \\
\text { Code }\end{array}$} & \multirow{2}{*}{$\begin{array}{c}\text { Combination } \\
\text { group }^{\dagger}\end{array}$} & \multicolumn{4}{|c|}{$\begin{array}{c}\text { Increasing Combination effects of } \\
\text { plant extracts using different solvents } \\
\left(\%^{*}\right)\end{array}$} \\
\hline & & $\begin{array}{c}\text { Ethanol } \\
95 \%\end{array}$ & $\begin{array}{c}\text { Hot } \\
\text { water }\end{array}$ & $\begin{array}{c}\text { Normal } \\
\text { water }\end{array}$ & Acetone \\
\hline \multirow{6}{*}{ A } & $\mathrm{P} / \mathrm{Ci}$ & 22.03 & 3.38 & 1.69 & 2.03 \\
\hline & $\mathrm{P} / \mathrm{N}$ & 15.25 & 3.38 & 1.69 & 50.85 \\
\hline & $\mathrm{P} / \mathrm{Ca}$ & 15.25 & 1.69 & 1.69 & 15.25 \\
\hline & $\mathrm{Ci} / \mathrm{N}$ & 23.72 & 3.38 & 3.38 & 61.02 \\
\hline & $\mathrm{Ci} / \mathrm{Ca}$ & 32.20 & 6.77 & 5.08 & 20.34 \\
\hline & $\mathrm{N} / \mathrm{Ca}$ & 11.86 & 3.38 & 3.38 & 13.56 \\
\hline \multirow{4}{*}{ B } & $\mathrm{P} / \mathrm{Ci} / \mathrm{N}$ & 28.81 & 8.64 & 18.64 & 25.42 \\
\hline & $\mathrm{P} / \mathrm{Ci} / \mathrm{Ca}$ & 30.50 & 13.55 & 13.55 & 15.25 \\
\hline & $\mathrm{P} / \mathrm{N} / \mathrm{Ca}$ & 7.11 & 20.33 & 20.33 & 30.51 \\
\hline & $\mathrm{Ci} / \mathrm{N} / \mathrm{Ca}$ & 25.42 & 6.94 & 20.33 & 22.03 \\
\hline $\mathrm{C}$ & $\mathrm{P} / \mathrm{Ci} / \mathrm{N} / \mathrm{Ca}$ & 25.42 & 10.16 & 5.08 & 30.51 \\
\hline
\end{tabular}

$†$ Combination group: P: black pepper; Ci: cinnamon; N: black cumin: Ca: cardamom; *All percentage represented in the table explain the calculation of antimicrobial susceptibility percentage of all 59oral isolate. 
These results were similar to the finding of Seth (2011), who investigated that the antimicrobial susceptibility of eight spices as an alternative to antibiotics in order to tackle these dangers. The combination of antibacterial susceptibility of common Indian spices namely black pepper, cardamom, cinnamon, clove, coriander seeds, garlic, ginger and turmeric against four potent food borne pathogens namely E. coli, Streptococcus ratti, Staphylococcus aureus and Bacillus cereus, he found that the combination of clove with black pepper, clove with turmeric, turmeric with black pepper, garlic with clove, garlic with turmeric, and garlic with black pepper, showed positive results against E. coli, S. ratti, and $S$. aureus [9].

Our study agrees with Ababutain (2011) that investigated the combination of clove and cinnamon have a broad spectrum antimicrobial susceptibility against $B$. subtilis and $C$. albicans at very low concentration MIC, which can be used as an alternative for antibiotics [10]. Despite the development of antimicrobial susceptibility in products, oral bacterial infections remain a major health problem because of environmental changes, as well as microorganism behaviors. Therefore, developing new antimicrobial compounds with high susceptibility, low toxicity and side effects is urgently needed. Our study showed that all of the studied medicinal plant combinations exhibited high antimicrobial susceptibility against oral isolates, with different synergistic or antagonistic effects.

\subsection{Mouthwash combination with plant extract ( 2 in 1)}

Data represented in Fig. 1 (a-c) show the antimicrobial susceptibility percentages against 59 oral isolates of 10 commercial mouthwashes combined with the highest plant extract combinations that were previously obtained. With $100 \%$ total mouthwash combined with plant extract combination $\mathrm{C}(\mathrm{P} / \mathrm{Ci} / \mathrm{N} / \mathrm{Ca})$ revealed higher antimicrobial susceptibility against oral isolates. Moreover, the similarity between the combination of mouthwash with plant extract combination $\mathrm{A}(\mathrm{Ci} / \mathrm{N})$ and B (P/N/Ca) exhibited the highest effect, with $80 \%$ antimicrobial susceptibility.

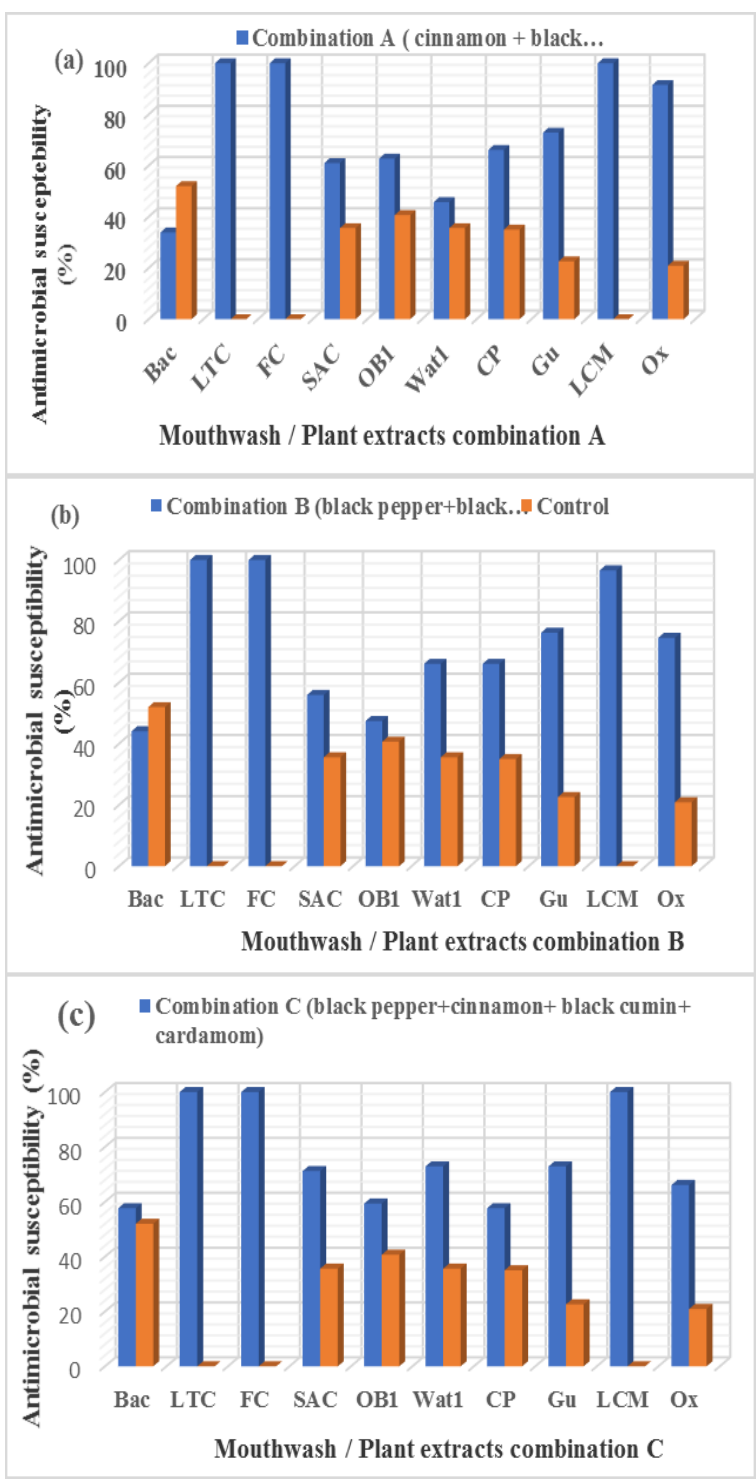

Fig. 1: Antimicrobial susceptibility percentages of combined action between 10 mouthwash (MW), Bac; LTC; FC; SAC; OB1; Wat1; $\mathrm{CP}$; $\mathrm{Gu}$; LCM; Ox, with plant extracts, (a) combination $\mathrm{A}(\mathrm{Ci} / \mathrm{N})$; (b) combination $\mathrm{B} \quad(\mathrm{P} / \mathrm{N} / \mathrm{Ca})$; (c) combination $\mathrm{C}(\mathrm{P} / \mathrm{Ci} / \mathrm{N} / \mathrm{Ca})$ against 59 oral isolates, control (MW plain). 
Plants have the major advantage of being the most effective and cheaper alternative source of drugs, medicinal plants extract have the potential to be used as therapeutic agents for chronic gingivitis and periodontitis conditions that have both bacterial and inflammatory components. These results were similar to the finding of Kothiwale et al. (2014), who reported that the mouth rinse containing medicinal plants have antimicrobial susceptibility against oral isolates, which may be useful as an adjunctive to mechanical therapy in the prevention and treatment of periodontal diseases [11]. Chentouf et al. (2012) who revealed a significant reduction in bacteria from children's oral cavity using miswak mouthwash extracts against microbial strains [12]. Mouthwash is used to complete the process of mechanical plaque removal, our results agreement with Mansour et al 2012 who reported that the garlic was a strong antimicrobial agent and acts as an inhibitor against both Gram-positive and Gram-negative bacteria, the efficacy of medicinal plant was higher than chlorhexidine against target bacteria and could be used as an effective mouthwash [13]. Finally, the combinations of medicinal plants $\mathrm{A}(\mathrm{Ci} / \mathrm{N}), \mathrm{B}(\mathrm{P} / \mathrm{N} / \mathrm{Ca})$, and $\mathrm{C}(\mathrm{P} / \mathrm{N} / \mathrm{Ca} / \mathrm{Ci})$ can be added to the mouthwash since it is inexpensive and available.

\section{Conclusion}

The acetonic plant extracts combinations of group $\mathrm{A}$ $(\mathrm{Ci} / \mathrm{N}), \mathrm{B}(\mathrm{P} / \mathrm{N} / \mathrm{Ca})$, and $\mathrm{C}(\mathrm{P} / \mathrm{N} / \mathrm{Ca} / \mathrm{Ci})$ with 10 different commercial mouthwash showed high antibacterial susceptibility against oral isolates.

The authors gratefully acknowledge Universiti Malaysia Pahang (UMP), Malaysia for the financial supported by grant GRS 140318 that enables the authors to accomplish this work.

\section{References}

1. A. Wan, ., J of Dent R., . 82,7(2003) p. 504508.

2. B. Oluremi .,TJ of Pharmaceutical Research,. 9,6(2010).

3. H.Koo., Archives of oral biology, 45,2(2000): $p$. 141-148.

4. Organization, W.H., WHO traditional medicine strategy 2002-2005. 2002.

5. Z. Aziz,and N. Tey,. Complementary Therapies in Medicine,. 17,1(2009): p. 44-50.

6. A. Gahlaut, and A.K. Chhillar,. Inter J of Pharmacy and Pharmaceutical Scie,. 5,2(2013): p. 372-376.

7. S Mukhtar,. and I. Ghori, . J. Appl. Biol. Pharm. Technol,. 3,2(2012): p. 131-136.

8. G Rao, G.,. Drugs,. 55,3(1998): p. 323-330.

9. A. Seth, A., Anti and phytochemical analysis,. 11,5(2011): p. 22-27.

10. I.M. Ababutain, ., Aust J Basic \& Appl Sci, . 5(2011): p. 678-683.

11. S.V. Kothiwale, S.V.,. J of Indian Society of Periodontology,. 18,3(2014): p. 316.

12. N. Chelli-Chentouf, N., .J of ethnoph,. 144,1(2012): p. 57-66.

13. A. Mansour, A., K. Maryam, and R. Neda, Jundishapur Journal of Micro,. 2(2012): p. 398-400. 